\title{
EFEKTIFITAS ASAM HUMAT DAN ARANG AKTIF TEMPURUNG KELAPA DALAM MENGADSORBSI RESIDU INSEKTISIDA ENDOSULFAN DI DALAM TANAH LATOSOL BOGOR
}

\author{
Lany Nurhayati ${ }^{1) *}$, RTM. Sutamihardja ${ }^{1)}$, Linggar Rudiarto \\ 1)*Program Studi Kimia FMIPA Universitas Nusa Bangsa Bogor \\ Jl. KH Soleh Iskandar KM 4 Cimanggu Tanah Sareal Bogor 16166 \\ *e-mail : lany@unb.ac.id
}

\author{
ABSTRACT
Effectiveness of Humic Acid and Active Charcoal of Coconut Shell on Adsorbtion the Residual Insecticide Endosulfan in Latosol Soil, Bogor

\begin{abstract}
In the study of humic acid and coconut shell activated charcoal (AATK) soaked in Humic Acid (5\% and 10\%) was left to dry for three days. The soil weighed as much as 10 grams mixed with activated charcoal soaked humic acid 5\% and $10 \%$ by series concentration of 500 ppm; $1000 \mathrm{ppm}$ and $1500 \mathrm{ppm}$, then added $20 \mathrm{~mL}$ of distilled water in each row shaken for one night, the soil was conditioned by the concentration of the insecticide endosulfan series: 12:05, 0,1, 0,2, 0,4, 0,8 and $1 \mathrm{ppm}$, did incubation. Example decanted, added $10 \mathrm{~mL}$ of acetone pa, filtered and then added with acetone as much as $10 \mathrm{~mL}$, the extract was evaporated to $1 \mathrm{~mL}$, then added by $10 \mathrm{~mL}$ acetone gradually. Results extract transferred into sample vials to be tested by using GC. Based on the analysis, it found residues of the insecticide endosulfan in Bogor Latosol soil with a concentration of 0.0005 ppm. The addition of coconut shell activated charcoal individually had a significant effect in reducing the content of endosulfan in soil, while the addition of humic acid individually did not have an appreciable impact in reducing residues of endosulfan in soil latosol. Insecticide endosulfan residues were able to be adsorbed by AATK and humic acid was 500 ppm and 10\% (A500H10) of 0,12178a ppm. The combination AATK and humic acids provide a real impact on the content of endosulfan residues in the soil latosol Bogor that could adsorb residual content in the soil.
\end{abstract}

Keywords: Organochlorines Insecticide Endosulfan, Humic Acid, Coconut Shell Charcoal On Land Latosol Bogor

\begin{abstract}
ABSTRAK
Pada penelitian asam humat dan arang aktif tempurung kelapa (AATK) direndam dalam Asam Humat (5\% dan 10\%) dibiarkan sampai mengering selama tiga hari.Tanah ditimbang sebanyak 10 gram dicampurkan dengan arang aktif yang sudah direndam asam humat 5\% dan 10\% dengan deret konsentrasi 500 ppm; 1000 ppm dan 1500 ppm, kemudian ditambahkan $20 \mathrm{~mL}$ aquades pada masing deret dikocok selama satu malam, tanah dikondisikan dengan deret konsentrasi insektisida endosulfan : 0,05, 0,1,0,2, 0,4, 0,8 dan $1 \mathrm{ppm}$, lakukan inkubasi. Contoh didekantasi, ditambahkan aseton pa $10 \mathrm{~mL}$, disaring kemudian ditambahkan dengan aseton sebanyak $10 \mathrm{~mL}$, hasil ekstrak dievaporasi sampai $1 \mathrm{~mL}$, kemudian ditambahkan aseton sebanyak $10 \mathrm{~mL}$ secara bertahap. Hasil Ekstrak dipindahkan kedalam botol sampel untuk diuji dengan menggunakan GC. Berdasarkan hasil analisis, masih ditemukan residu insektisida endosulfan di tanah Latosol Bogor dengan konsentrasi 0,0005 ppm. Penambahan arang aktif tempurung kelapa secara individual memiliki pengaruh yang cukup signifikan dalam mengurangi kandungan endosulfan dalam tanah, sedangkan penambahan asam humat secara individual tidak memiliki pengaruh yang cukup besar dalam mengurangi kandungan residu endosulfan dalam tanah latosol. Residu insektisida endosulfan terbaik mampu diadsorbsi oleh AATK dan asam humat adalah $500 \mathrm{ppm}$ dan 10\% (A500H10) sebesar 0,12178a ppm. Kombinasi AATK dan asam humat memberikan pengaruh yang nyata terhadap kandungan residu endosulfan didalam tanah latosol bogor sehingga dapat mengadsorbsi kandungan residu didalam tanah.
\end{abstract}

Kata Kunci : Insektisida Organoklorin Endosulfan, Asam Humat, Arang Aktif Tempurung Kelapa, Tanah Latosol Bogor 


\section{PENDAHULUAN}

Penggunaan insektisida telah dilarang penggunaannya, terutama insektisida organoklorin karena sifatnya yang persisten, tetap aktif hingga bertahun-tahun dan memberikan dampak buruk terhadap lingkungan. Pestisida golongan organoklorin merupakan jenis pestisida yang paling baik digunakan untuk mengendalikan serangga (Sastroutomo, 1992).

Organoklorin digunakan secara luas di sektor pertanian karena keefektifan dan harganya yang murah, namun insektisida jenis ini memiliki sifat persisten dan toksik. Sifat persisten organoklorin telah dibuktikan oleh berbagai penelitian, dengan masih ditemukannya residu-residu dari berbagai jenis insektisida organoklorin di daerah pertanian meskipunn sudah tidak digunakan lagi oleh petani (Ramadhani dan Oginawati, 2011). Tingginya penggunaan pestisida disebabkan kurangnya pengetahuan petani terhadap dampak negatif dari penggunaan pestisida yang berlebih terhadap lingkungan, keengganan para petani terhadap resiko kegagalan panen dan keinginan para petani untuk mendapatkan hasil panen yang lebih banyak dari panen sebelumnya.

Endosulfan merupakan insektisida jenis organoklorin. Endosulfan bertindak sebagai racun kontak terhadap berbagai serangga dan tungau tertentu pada sereal, kopi, kapas, buah, biji, kentang, teh, sayur dan tanaman lain. Endosulfan juga dapat digunakan sebagai pengawet kayu, dijual sebagai campuran dari alpha dan beta - endosulfan. Endosulfan berwarna krem hingga coklat dan baunya seperti terpentin, merupakan zat yang sangat beracun. Organisasi kesehatan dunia mengklasifikasikan endosulfan di kategori II (cukup berbahaya) sedangkan US Environmental Protection Agency (US EPA) mengklasifikasikan sebagai kategori Ib (Sangat berbahaya), sifat toksisitas jangka pendeknya tinggi. Endosulfan mudah diserap oleh perut, paru-paru, dan kulit, yang berarti bahaya endosulfan dapat masuk melalui semua rute paparan.

Salah satu langkah mengatasi akumulasi insektisida ini adalah dengan digabungnya asam humat dan arang aktif tempurung kelapa (AATK) untuk meng- adsorpsi endosulfan lebih baik.Asam humat berperan dalam memperbaiki kondisi tanah dan pertumbuhan tanaman karena memiliki kapasitas tukar kation yang tinggi, kemampuan mengikat air yang besar, dan sifat adsorpsi, sebagai zat pengompleks serta kemampuan untuk mengikat polutan dalam tanah. AATK diketahui memiliki rongga yang sangat disukai oleh mikroba (bakteri tanah pendegradasi dan bakteri pengikat nitrogen) sebagai tempat tinggal, sehingga populasi mikroba tersebut menjadi meningkat dikarenakan di dalam rongga arang aktif terdapat nutrient $\mathrm{C}$ dan $\mathrm{N}$ yang berasal dari residu pestisida. Residu pestisida yang terperangkap di dalam rongga arang aktif akan didegradasi oleh mikroba pendegradasi sehingga residu pestisida akan terurai. (Anonim, 2013).

Penelitian kali ini akan diuji efektifitas asam humat dan arang aktif sebagai upaya mengadsorbsi residu endosulfan dalam tanah.

\section{BAHAN DAN METODA}

\section{Bahan dan Peralatan}

Bahan yang digunakan dalam penelitian ini terdiri dari penelitian yang digunakan untuk ekstraksi, yaitu : AATK ukuran 80 Mesh, asam humat 5\% dan 10\%, endosulfan, n-heksan pa, aseton pa, $\mathrm{Na} 2 \mathrm{SO} 4$ anhidrat dan Tanah Latosol Bogor.

Peralatan yang digunakan dalam penelitian ini terdiri dari Kromatografi gas Varian $450 \mathrm{GC}$ yang dilengkapi dengan Electron Capture Detector (ECD) dan jenis kolom kromatografi VF-1701 pesticide, rotavavor, Mesh 16, Mesh 80, gunting, timbangan Analitik, pipet volume, shaker, botol timbang, dan alat-alat gelas lainnya.

\section{Metode Penelitian}

Metode penelitian ini merupakan metode eksperimental menggunakan Rancangan Acak Lengkap (RAL) dengan 6 perlakuan konsentrasi endosulfan, 3 perlakuan konsentrasi asam humat, 4 perlakuan konsentrasi AATK. 
Keterangan Perlakuan :

Residu Insektisida Endosulfan 0,05; 0,1; 0,2; 0,4; 0,8 dan $1 \mathrm{ppm}$

A0HO : Arang Aktif Tempurung Kelapa 0 ppm, Asam Humat 0 $\%$

A500H5 : Arang Aktif Tempurung Kelapa 500 ppm, Asam Humat $5 \%$

A500H10 : Arang Aktif Tempurung Kelapa 500 ppm, Asam Humat $10 \%$

A1000H5 : Arang Aktif Tempurung Kelapa 1000 ppm, Asam Humat $5 \%$

A1000H10 : Arang Aktif Tempurung Kelapa 1000 ppm, Asam Humat $10 \%$

A1500H5 : Arang Aktif Tempurung Kelapa 1500 ppm, Asam Humat $5 \%$

A1500H10 : Arang Aktif Tempurung Kelapa 1500 ppm, Asam Humat $10 \%$

\section{Preparasi Arang Aktif dan Asam Humat}

Asam humat $100 \%$ yang diperoleh diencerkan menjadi $5 \%$ dan $10 \%$. AATK digiling halus dengan penggiling diayak dengan ukuran 80 mesh. Setelah itu direndam dalam AATK dan Asam Humat (5\% dan 10\%) dengan perbandingan $50 \mathrm{~g}$ AATK, $100 \mathrm{ml}$ asam humat dibiarkan sampai mengering selama tiga hari.

\section{Preparasi Tanah}

Tanah Latosol Bogor yang diperoleh dikeringanginkan lalu tumbuk sedikit demi sedikit dengan lumpang dan alu.Kemudian disaring dengan ayakan $1 \mathrm{~mm}$ ukuran 16 Mesh.

\section{Uji Efektifitas Adsorbsi Endosulfan dalam Tanah}

Tanah ditimbang sebanyak 10 gram dicampurkan dengan arang aktif yang sudah direndam asam humat 5\% dan $10 \%$ dengan deret konsentrasi 500 ppm; 1000 ppm dan $1500 \mathrm{ppm}$, kemudian ditambahkan $20 \mathrm{~mL}$ aquades pada masing deret dikocok selama satu malam, tanah dikondisikan dengan deret konsentrasi Insektisida Endosulfan : 0,$05 ; 0,1 ; 0,2 ; 0,4 ; 0,8$ dan 1 ppm, lakukan
Inkubasi dalam waktu satu minggu pada kondisi suhu kamar sambil dikocok horizontal dua kali sehari.

\section{Ekstrak Contoh}

Contoh didekantasi, ditambahkan aseton pa $10 \mathrm{~mL}$, dikocok horizontal selama 1 jam, disaring dan tanah ditambahkan aseton sebanyak $10 \mathrm{~mL}$, hasil ekstrak dievaporasi sampai $1 \mathrm{~mL}$, kemudian ditambahkan aseton sebanyak $10 \mathrm{~mL}$ secara bertahap. Hasil Ekstrak dipindahkan kedalam botol sampel untuk diuji dengan menggunakan GC.

\section{Perhitungan Konsentrasi Residu Endosulfan}

Konsentrasi residu endosulfan dihitung dengan cara mengukur tinggi puncak kromatogram kemudian dimasukkan dalam persamaan (Komisi Pestisida, 1997) :

Konsentrasi Residu : $\mathrm{R}=\mathrm{Ac} / \mathrm{As} \times \mathrm{Ks} \times \mathrm{Fc} / \mathrm{Bc}$

Keterangan :

$\mathrm{R}=$ Residu (ppm)

Ac $=$ Area Contoh $(\mu$ V.min $)$

As $=$ Area Standar $(\mu$ V.min)

$\mathrm{Ks}=$ Konsentrasi Standar (mg/gr)

$\mathrm{Bc}=$ Bobot Contoh (gr)

$\mathrm{Fc}=$ Faktor Pengenceran $(\mathrm{ml})$

\section{HASIL DAN PEMBAHASAN}

\section{Analisis Fisik dan Kimia Tanah Latosol}

Penentuan tekstur dilakukan berdasarkan analisis fisik tanah, tanah Latosol Bogor memiliki kandungan pasir 17\%, debu 38\%, dan liat $48 \%$. Berdasarkan hasil analisis, berdasarkan angka tersebut tanah ini dapat digolongkan sebagai tanah bertekstur liat berdebu (silty clay). Penetuan sifat fisik dan kimia tanah Latosol Bogor juga menunjukkan nilai $\mathrm{pH}$ tanah dengan metode pelarutan dalam $\mathrm{H}_{2} \mathrm{O}$ dengan perbandingan 1:5 didapat nilai $\mathrm{pH}$ sebesar 5,62 maka dengan nilai tersebut tanah Latosol Bogor tergolong agak masam. Susunan kation dalam tanah ini meliputi $0,63 \mathrm{me} / 100 \mathrm{~g} \mathrm{Ca}$ (sangat rendah); $10,32 \mathrm{me} / 100 \mathrm{~g} \mathrm{Mg}$ (sangat tinggi); 6,53 me/100g K (sangat tinggi) dan $0,18 \mathrm{me} / 100 \mathrm{~g} \mathrm{Na}$ (rendah). Nilai KTK dan 
kejenuhan basa (KB) yang diperoleh berturut-turut $13,78 \%$ (rendah) dan $>100 \%$ (sangat tinggi).

Tanah yang mempunyai kandungan mineral liat mempunyai kemampuan mengadsorpsi bahan-bahan organik di dalam tanah, dengan kemampuan tersebut mineral liat panah latosol Bogor mempunyai potensi yang besar dalam menyerap pestisida endosulfan dibandingkan dengan tanah yang mempunyai kandungan pasir yang tinggi.

Insektisida endosulfan mempunyai persistensi yang lebih kuat pada kondisi tanah yang mempunyai nilai $\mathrm{pH}$ asam atau hampir netral, waktu paruh endosulfan dalam air lebih kurang 4 hari, tetapi kondisi $\mathrm{pH}$ yang rendah akan memperpanjang masa waktu paruhnya. Dalam air endosulfan dapat didegradasi berupa senyawa endosulfan sulfat (WHO, 1992 dalam Arianti 2002), tingkat kemasaman tanah latosol tergolong masam artinya keadaan tanah yang masam menyebabkan tanah kehilangan kapasitas tukar kation dan kemampuan menyimpan hara kation dalam bentuk dapat tukar, karena perkembangan muatan positif.

Kapasitas Tukar Kation menyatakan jumlah tapak aktif adsorpsi kation per satu satuan bobot tanah. Kandungan KTK tanah latosol rendah artinya kandungan bahan organiknya rendah, daya jerap kation rendah. Hal ini sesuai dengan pendapat Hardjowigeno (2002) bahwa tanah dengan KTK rendah mampu menjerat dan menyediakan unsur hara tidak lebih baik daripada tanah dengan KTK tinggi.

\section{Uji Efektifitas AATK dan Asam Humat terhadap Residu Insektisida Endosulfan dalam Tanah Latosol}

Tanah Latosol Bogor terlebih dahulu dianalisis kandungan residu insektisida endosulfan dengan tujuan untuk mengetahui kondisi awal konsentrasi residu endosulfan pada tanah, berdasarkan hasil analisis awal, tanah mengandung residu endosulfan sebesar 0,0005 ppm.

Uji efektifitas endosulfan di tanah setelah inkubasi satu minggu diperoleh bahwa penurunan konsentrasi residu insektisida endosulfan di dalam tanah berkisar antara 80,36\% - 95,00\%, karena adanya penjerapan senyawa endosulfan oleh asam humat dan arang aktif tempurung kelapa.

Pengaruh perlakuan kombinasi AATK terhadap Konsentrasi Residu Endosulfan dalam Tanah Latosol Bogor

Tabel 1. Pengaruh Konsentrasi Arang Aktif terhadap Residu Endosulfan

\begin{tabular}{ccc}
\hline No & Perlakuan & $\begin{array}{c}\text { Konsentrasi } \\
\text { Endosulfan }(\mathrm{ppm})\end{array}$ \\
\hline 1 & A0 & $0,04705 \mathrm{ab}$ \\
2 & A500 & $0,10066 \mathrm{a}$ \\
3 & A1000 & $0,03021 \mathrm{~b}$ \\
4 & A1500 & $0,02338 \mathrm{~b}$ \\
\hline
\end{tabular}

Keterangan : Angka-angka yang diikuti oleh huruf yang sama pada kolom yang sama tidak berbeda nyata pada tingkat kepercayaan $95 \%$

Pada Tabel 1, dapat disimpulkan bahwa konsentrasi arang aktif pada penambahannya berpengaruh pada konsetrasi residu insektisida dalam tanah. Hal tersebut dapat dilihat pada konsentrasi arang aktif yang menunjukkan angka yang signifikan dengan adanya lambang a,b, dan ab pada kolom konsentrasi endosulfan namun jumlah daya jerap tertinggi terdapat pada konsentrasi arang aktif $500 \mathrm{ppm}$.

\section{Pengaruh perlakuan kombinasi asam humat terhadap konsentrasi residu endosulfan dalam Tanah Latosol Bogor}

Tabel 2. Pengaruh Konsentrasi Asam Humat dalam Tanah

\begin{tabular}{ccc}
\hline No & Perlakuan & $\begin{array}{c}\text { Konsentrasi } \\
\text { Endosulfan (ppm) }\end{array}$ \\
\hline 1 & H0 & $0,04705 \mathrm{a}$ \\
2 & H5 & $0,03980 \mathrm{a}$ \\
3 & H10 & $0,06303 \mathrm{a}$ \\
\hline
\end{tabular}

Keterangan : Angka-angka yang diikuti oleh huruf yang sama pada kolom yang sama tidak berbeda nyata pada tingkat kepercayaan $95 \%$

Pada Tabel 2, dapat disimpulkan pada penambahan asam humat tidak memiliki pengaruh yang cukup signifikan terhadap konsentrasi residu insektisida dalam tanah. Sehingga pemberian asam humat dalam 
jumlah yang sedikit maupun banyak tidak memiliki pengaruh yang jauh berbeda. Hal tersebut bisa saja disebabkan oleh kondisi tanah yang sebenarnya sudah mengandung humus, sehingga penambahan asam humat terhadap tanah tidak banyak mempengaruhi.

\section{Pengaruh Perlakuan Kombinasi Asam Humat dan AATK terhadap Konsentrasi Residu Endosulfan dalam Tanah Latosol Bogor}

Tabel 3. Uji lanjut Pengaruh Perlakuan Kombinasi antara Asam Humat dan Arang Aktif

\begin{tabular}{ccc}
\hline No & Perlakuan & $\begin{array}{c}\text { Konsentrasi } \\
\text { Endosulfan }(\mathrm{ppm})\end{array}$ \\
\hline 1 & A0H0 & $0,04705 \mathrm{ab}$ \\
2 & A500H5 & $0,07953 \mathrm{ab}$ \\
3 & A500H10 & $0,12178 \mathrm{a}$ \\
4 & A1000H5 & $0,00913 \mathrm{~b}$ \\
5 & A1000H10 & $0,05128 \mathrm{ab}$ \\
6 & A1500H5 & $0,03073 \mathrm{~b}$ \\
7 & A1500H10 & $0,01603 \mathrm{~b}$ \\
\hline
\end{tabular}

Keterangan : Angka-angka yang diikuti oleh huruf yang sama pada kolom yang sama tidak berbeda nyata pada tingkat kepercayaan $95 \%$

Pada Tabel 3. Namun kombinasi antara asam humat dan arang aktif mempengaruhi kandungan residu pestisida dalam tanah yaitu pada konsentrasi arang aktif 500 ppm dan asam humat $10 \%$. Residu insektisida dalam tanah yang mampu dijerap cukup banyak sehingga tidak menimbulkan pencemaran ke tempat lain yang memungkinkan insektisida terbawa oleh aliran air, namun dengan adanya arang aktif sisa residu insektisida yang terjerap arang aktif setelah adanya asam humat yang membantu proses degradasi dengan bantuan mikroba tanah cukup baik sehingga mengurangi residu endosulfan dalam air.

\section{KESIMPULAN}

Berdasarkan hasil analisis, masih ditemukan residu insektisida endosulfan di tanah Latosol Bogor dengan konsentrasi 0,0005 ppm. Penambahan arang aktif tempurung kelapa secara individual memi- liki pengaruh yang cukup signifikan dalam mengurangi kandungan endosulfan dalam tanah, sedangkan penambahan asam humat secara individual tidak memiliki pengaruh yang cukup besar dalam mengurangi kandungan residu endosulfan dalam tanah latosol. Namun kombinasi arang aktif 500 ppm dan asam humat 10\% (A500H10) masih efektif dalam menurunkan kandungan residu insektisida endosulfan didalam tanah Latosol Bogor.

\section{DAFTAR PUSTAKA}

Adiwisastra, A. 1985. Keracunan, Sumber Bahaya serta Penanggulangannya, Penerbit Angkasa, Bandung.

Arianti, F.D. 2002. Toksisitas insektisida endosulfan terhadap ikan nila (Oreochromis niloticus) dalam lingkungan air tawar. Tesis. Program Pascasarjana, IPB. Bogor. 87 hal.

Anshari A. F. 2010. Pencemaran organoklorin. Fakultas Teknik Lingkungan. Universitas Lambung mangkurat

Arsiati, A. 2002. Sifat-sifat Asam Humat Hasil Ekstraksi dari Berbagai Jenis Bahan dan Pengekstrak. Skripsi. Program Studi Ilmu Tanah, Fakultas Pertanian, Institut Pertanian Bogor. Bogor.

Brady, N. C. 1990. The Nature and Properties of soil. 10th ed. The Macmillan CO. New York.

Brady, N. C. and Weil, R. R. 2002.The Nature and Properties of soil.13th ed. Prentice Hal. New Jersey.

Budi, A. 2002. Adsorbsi Insektisida Karbofuran Oleh Karbon Aktif Sekam Padi dan Tempurung Kelapa pada Tanah Inseptisol Karawang dan Ultisol Jasinga. Skripsi. Program Studi Kimia, Fakultas Matematika dan Ilmu Pengetahuan Alam, Institut Pertanian Bogor. Bogor. 
Cory, Y.D. 2001. Pengaruh Kadar Perekat dan Tekanan Kempa Terhadap Sifat Fisis dan Kimia Briket Arang dari Serasah Daun Acacia Manguin Willd.Skripsi. Bogor: Institut Pertanian Bogor.

Djatmiko B, S. Ketaren, dan S Setyahartini.1985. Pengolahan Arang dan Kegunaannya. Di Dalam Rasjiddin I. 2006. Pembuatan Arang Aktif Dari Tempurung Biji Jambu Mede (Anacardium occidentale) Sebagai Adsorben Pada Pemurnian Minyak Goreng Bekas.Skripsi. Bogor: Institut Pertanian Bogor.

Goenadi, D. H and I. Mariska. 1995. Shot Initiation and Growth Enchanment by Humic Acid in Tissue Culture of some Crops Species. Plant Cell Rep. 15: 5962.

Hardjowigeno, S. 1985. Genesis dan Klasifikasi Tanah.Fakultas Pasca Sarjana Institut Pertanian Bogor.

Hardjowigeno, S. Ilmu Tanah. PT. Mediyatama Sarana Perkasa. Jakarta. 1987.

Hendra D dan Pari G. 1999. Pembuatan Arang Aktif Dari Tandan Kosong Kelapa Sawit. Buletin Penelitian Hasil Hutan. Vol 17 : 113-122.

http://diperta.jabarprov.go.id/index.php/sub menu/informasi/berita/detailberita/48 diakses tanggal 26 Juni 2013

http://18arnev.blogspot.com/2011/02/asamhumat-humic-acid.html diakses tanggal 26 Juni 2013

Kirana.1985. Pengaruh Tekanan Pengempa dan Jenis Perekat dalam pembuatan Brieket Arang dari Tempurung Kelapa Sawit (Elaesis quinensis Jacq).

Kirk, R.E. dan D.F. Othmer. 1964. Encyclopedia of chemical
Technology, The Interscince Inc, Ney York.

Komisi Pestisida. 1990. Pedoman pengujian residu pestisida dalam hasil pertanian; Pelaksanaan ketentuan batas maksimum residu pestisida. Direktoran Perlindungan Tanaman Pangan, Departemen Pertanian RI.

Lestari, A. 2006. Studi Pemanfaatan Asam Humat Hasil Ekstraksi dari Andosol dan Gambut dalam Pertumbuhan Semaian Padi. Skripsi. Program Studi Ilmu Tanah, Fakultas Pertanian, Institut Pertanian Bogor. Bogor.

Natawigena. 1985. Pestisida dan Kegunaannya, cetakan kedua. Bandung : Penerbit Armico.

Orlov, D. S. 1985. Humus Acid of Soil.Moscow University Publisher. Moscow. 378 pp.

Panut Djojosumarto. 2008. Pestisida dan Aplikasinya. Penerbit PT.Agromedia Pustaka, Jakarta

Peraturan Pemerintah Republik Indonesia Nomor 7 Tahun 1973 dan Nomer 6 Tahun 1995.

Peraturan Pemerintah Republik Indonesia Nomor 20 Tahun 1990.

Pohan, N. 2004. Pestisida dan Pencemarannya. Universitas Sumatra Utara.

Prijanto, T.B. 2009. Analisis Faktor Risiko Keracunan Pestisida Organofosfat pada Keluarga Petani Hortikultura Di Kecamatan Ngablak Kabupaten Magelang.Tesis.Program Pascasarjana Universitas Diponegoro Semarang.

Priyanto. 2007. Toksisitas, Obat, Zat kimia dan terapi antidotum. Leskonfi. Jabar.

Rachmawati S.D.2004. Pembuatan Arang Aktif Tempurung Kelapa Sawit Untuk Pemurnian Minyak Goreng 
Bekas.Skripsi. Bogor : Institut Pertanian Bogor.

Ramadhani. W. N., dan K. Oginawati. 2011. Residu insektisida organoklorin di persawahan Sub Das Citarum Hulu. Program Studi Teknik Lingkungan, Institut Teknologi Bandung: Bandung.

Sastroutomo, S. S. 1992.Pestisida : Dasardasar dan Dampak Penggunaannya. PT Gramedia Pustaka Utama, Jakarta.

Schnitzer, M and S. Khan U. 1978. Soil Organic Matter. Elsevier Scientific Publising Compani. Amsterdam.

SNI. 1995. SNI 06-3730-1995 : Arang Aktif Teknis. Jakarta : Dewan Standarisasi Nasional.

Soedarmo, S. 1990. Pestisida Tanaman. Jakarta : Kanisius.

Soepardi, G. 1983. Sifat dan Ciri Tanah. Departemen Tanah. Fakultas Pertanian. Institut Pertanian Bogor. Bogor.

Soepraptohardjo, M. 1961. Sistem Klasifikasi Tanah di Balai Penyelidikan Tanah. KNIT I, Bogor

Sulaksono, I.C. 2001. Kajian jenis dan tingkat residu insektisida serta pengaruhnya terhadap komunitas makrozoobentos di sentra produksi padi Pantai Utara Jawa Barat. Tesis . Program Pascasarjana, IPB. Bogor. 98 hal.

Stevenson, F. J. 1982. Humus Chemistry : Genesis, Composition, Reactions. A. Willey \& Sons, Inc.New York.

Sudrajat R, Soleh S. 1994. Petunjuk Teknis Pembuatan Arang Aktif. Bogor : Puslitbang Hasil Hutan dan Sosial Ekonomi Kehutanan.

Sururi, A. 2008. Penetapan Bahan Aktif Dimehypo dalam Produk Formulasi Insektisida secara Kromatografi Cairan Tingkat Tinggi. Skripsi. FMIPA Kimia Bogor: Universitas Nusa Bangsa.

Tan, K. H. 1993. Principles of Soil Chemistry. Marcel Dekker Inc. New York.

Wardani, N. 2002.Pengaruh Pemberian Asam Humat Sebagai Bahan Ameliorant Tanah terhadap Pertumbuhan dan Serapan Timbal Tanaman Bayam pada Tanah yang Tercemar Logam Berat Timbal (Pb).Skripsi. Program Studi Ilmu Tanah, Fakultas Pertanian, Institut Pertanian Bogor. Bogor.

Wudianto, R. 1997. Petunjuk Penggunaa Pestisida. Jakarta : Penebar Swadaya. 
Lampiran 1. Kromatogram residu endosulfan

\section{Chromatogram:}

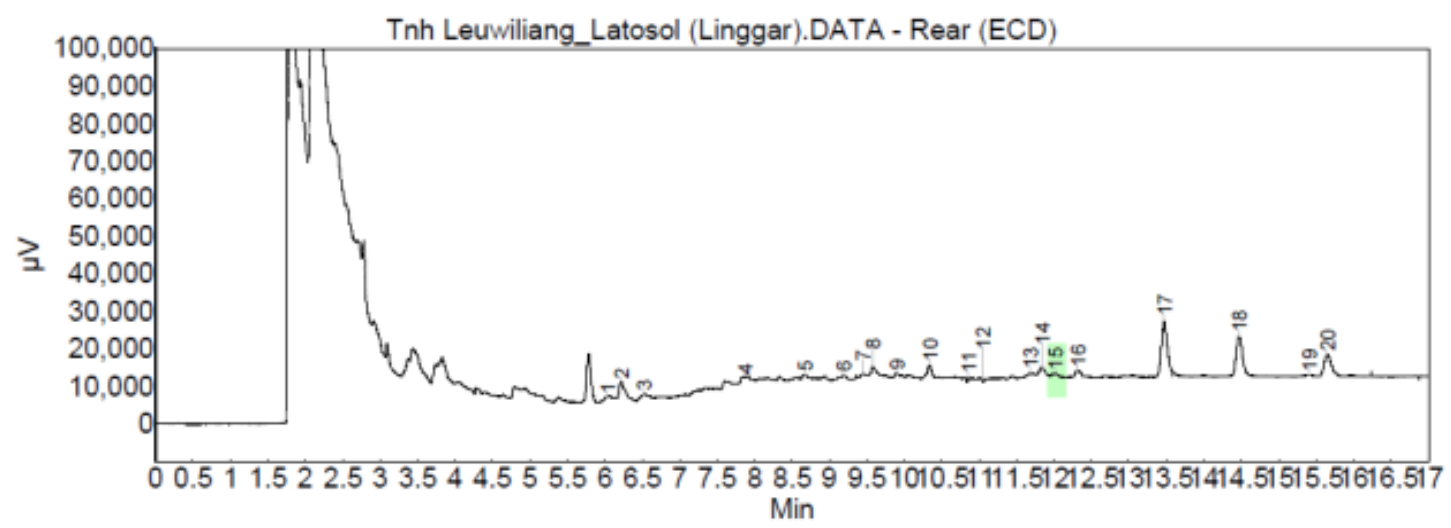

Gambar 1. Kromatogram Residu Endosulfan dalam Tanah Latosol Setelah Inkubasi.

\section{Keterangan:}

Hasil analisa KG (Kromatografi Gas) diperoleh residu endosulfan (15) di tanah latosol setelah inkubasi 1 minggu dengan konsentrasi $5 \mathrm{ng} / \mathrm{g}$ dengan waktu retensi 12,01 menit. 